\title{
Use of golden mussel and wattle tannin in the supply of cut chickens
}

\section{Utilização de mexilhão dourado e tanino de acácia na alimentação de frangos de corte}

\author{
Douglas Fernando Bayerle ${ }^{1 *}$; Ricardo Vianna Nunes ${ }^{2}$; Lucas Wachholz ${ }^{3}$; Taciana \\ Maria de Oliveira Bruxel²; José Geraldo de Vargas Junior ${ }^{4}$; Gabriela Sangalli; \\ Talita Vitória Giron ${ }^{1}$; Rodrigo André Schone ${ }^{1}$
}

\begin{abstract}
This study aimed to evaluate the use of acacia tannin as a toxic metal adsorbent in the diets of broilers fed with the inclusion of golden mussel meal in substitution for calcitic limestone. In the first trial, 648 male 21-day-old animals were divided among six treatments and six replicates, with 18 birds per experimental unit, organized in a completely randomized design (DIC). The treatments were diets with different acacia tannin levels $\left(0,250,500,750,1000\right.$, or $1250 \mathrm{~g}^{-1}$ ton $\left.^{-1}\right)$. The results indicated that $250 \mathrm{~g}$ ton $^{-1}$ of tannin was not harmful to weight gain, final weight, or feed conversion. Tannin levels caused a decrease in carcass yield and fat deposition and an increase in liver size. For the second trial, 900 male broilers of 21 days of age were used and distributed in a DIC, with different levels of substitution of calcitic limestone by the golden mussel meal $(0,25,50,75$, or $100 \%)$ and supplementation or not with acacia tannins $\left(250 \mathrm{~g} \mathrm{ton}^{-1}\right)$, with 5 replicates and each experimental unit being composed of 18 birds. The performance data show that the use of $250 \mathrm{~g} \mathrm{ton}^{-1}$ of tannin is detrimental to bone performance and resistance and golden mussel meal can be used to substitute up to $100 \%$ of the limestone in the diets without affecting the variables studied.
\end{abstract}

Key words: Alternative foods. Birds. Calcium. Limnoperna fortunei.

\section{Resumo}

Este estudo objetivou avaliar a utilização de tanino de acácia como adsorvente de metais tóxicos em dietas de frangos de corte alimentados com inclusão da farinha de mexilhão dourado em substituição ao calcário calcítico. No primeiro ensaio foram utilizados 648 animais, machos, de 21 dias de idade divididos em seis tratamentos e seis repetições, com 18 aves por unidade experimental, organizados em delineamento inteiramente casualizado (DIC). Os tratamentos foram constituídos por dietas com níveis de tanino de acácia $\left(0,250,500,750,1000,1250 \mathrm{~g}\right.$ ton $\left.^{-1}\right)$. Os resultados apontaram que o nível de 250 $\mathrm{g} \mathrm{ton}^{-1}$ de tanino não foi prejudicial para ganho de peso, peso final e conversão alimentar. Os níveis de tanino provocam diminuição no rendimento de carcaça, deposição de gordura e aumento no tamanho do fígado. Para o segundo ensaio foram utilizados 900 frangos de corte machos de 21 dias de idade

1 Discentes, Curso de Mestrado do Programa de Pós-Graduação em Zootecnia, PPZ, Universidade Estadual do Oeste do Paraná, UNIOESTE, Marechal Cândido Rondon, PR, Brasil. E-mail: douglas_fernandob@hotmail.com; gabrielasangalli@hotmail.com; talitagiron@hotmail.com; rodrigoschone87@gmail.com

2 Profs., UNIOESTE, Centro de Ciências Agrárias, CCA, Marechal Cândido Rondon PR, Brasil. E-mail: nunesrv@hotmail.com; tacideoliveira@hotmail.com

3 Discente, Curso de Doutorado do Programa de Pós-Graduação em Zootecnia, PPZ, Universidade Estadual do Oeste do Paraná, UNIOESTE, Marechal Cândido Rondon, PR, Brasil. E-mail: lucaswach@hotmail.com

4 Prof., Universidade Federal do Espírito Santo, UFES, Centro de Ciências Agrarias, CCA, Alegre, ES, Brasil. E-mail: josegeraldovargas@yahoo.com.br

* Author for correspondence 
distribuídos em DIC, com níveis de substituição de calcário calcítico pela farinha de mexilhão dourado $(0 ; 25 ; 50 ; 75 ; 100 \%)$ e suplementação ou não com tanino de acácia $\left(250 \mathrm{~g}\right.$ ton $\left.^{-1}\right)$ e 5 repetições, sendo as unidades experimentais compostas por 18 aves. Os dados de desempenho demonstram que, a utilização de $250 \mathrm{~g} \mathrm{ton}^{-1}$ de tanino é prejudicial para o desempenho e resistência óssea e a utilização do mexilhão pode ser realizada em até $100 \%$ em substituição ao calcário das dietas sem afetar as variáveis estudadas.

Palavras-chave: Alimentos alternativos. Aves. Cálcio. Limnoperna fortunei.

\section{Introduction}

Among the activities that drive the Brazilian agricultural sector, the poultry industry stands out, largely due to the modernization of the sector, but especially due to its production and supply of large amounts of animal protein in a short time at a low cost. In order to reduce poultry production costs, nutritionists are looking for ways to use ingredients that have low commercial value in feed formulation. The use of exotic organisms, such as the golden mussel, which is a freshwater mollusc from China and South-East Asia, which was accidentally introduced to South America (DARRIGRAN et al., 2012), might be a viable alternative due to its low economic importance, together with the need to control the population.

According to Bayerle et al. (2017), the golden mussel (Limnoperna fortunei) presents great potential to be used as food for animals. The processing of this species generates golden mussel meal, which can be used in rations as a source of calcium, since the corporal structure of the species is constituted mainly of calcium carbonate $\left(\mathrm{CaCO}_{3}\right)$. However, due to its filtering habit, this species has the ability to store contaminants, such as toxic metals, in its body (MARENGONI et al., 2013), which have a cumulative effect on organisms (LIMA et al., 2015) and on the health of humans and animals (PANDEY; MADHURI, 2014).

Thus, for the golden mussel to be used in animal diets, the effects of the toxic metals that might be present in its body need to be minimized. Tannins are phenolic compounds that have a great sequestering ability, that is, they bind to proteins and polymers, preventing their absorption in the gastrointestinal tract of animals (MARTINEZ, 1996).
Tannins are classified as water-soluble or condensed tannins. They are polyphenols of vegetable origin, are soluble in water, and have the ability to bind and precipitate various types of amino acids and polysaccharides. The tannins of black acacia are, according to Calegari et al. (2016), mostly condensed.

According to Nakano et al. (2001), tannins have considerable capacity to adsorb toxic metals. Thus, the use of tannins as an adsorbent of these contaminants can be a practice used to reduce the contamination of the meat of broilers and, consequently, to avoid food poisoning in humans. However, it is necessary to evaluate the levels of tannin inclusion in broiler rations that does not compromise poultry production, since according to Figueiredo et al. (2003) and Garcia et al. (2005), tannins might cause changes in the intestinal mucosa of broiler chickens.

Thus, there is a great potential for the use of golden mussel as a source of calcium in broiler diets and due to the possible contamination with toxic heavy metals, there is a need to use an adsorbent, thus making the use associated with acacia tannin a good alternative. This experiment was therefore developed with the objective of evaluating the use of acacia tannins as an adsorbent of toxic metals in broiler feeds with different levels of inclusion of the golden mussel meal to replace calcareous limestone in the diets.

\section{Material and Methods}

Two experiments were carried out in the experimental aviary at the State University of the West of Paraná, UNIOESTE. All procedures were 
authorized by the ethics committee on animal experimentation and practical lessons of Unioeste, under the protocol number 56/13.

For the first experiment, 648 male broilers of the Cobb 500 lineage from 1 to 21 days of age received water and feed at will, which was formulated (Table
1) to meet the nutritional requirements of birds. At 21 days of age, the birds were individually weighed and distributed in the experimental units in a completely randomized design (DIC), with six treatments and six replicates, totaling 36 experimental units, each with 18 birds and an average weight of $911.5 \pm 3.9$ grams.

Table 1. Diet composition.

\begin{tabular}{|c|c|}
\hline Ingredients $(\%)$ & Initial \\
\hline Corn grain & 57.68 \\
\hline Soybean meal & 32.99 \\
\hline Degummed soy oil & 4.500 \\
\hline Monocalcium phosphate & 0.965 \\
\hline Limestone & 0.957 \\
\hline Salt & 0.396 \\
\hline DL-methionine $99 \%$ & 0.303 \\
\hline L-lysine $78 \%$ & 0.282 \\
\hline L-threonine99\% & 0.132 \\
\hline Vitamin suplement $^{1}$ & 0.100 \\
\hline Mineral suplement ${ }^{2}$ & 0.050 \\
\hline Choline chloride $60 \%$ & 0.060 \\
\hline Antioxidant $^{3}$ & 0.020 \\
\hline Coxistac $^{4}$ & 0.060 \\
\hline Stafac $500^{5}$ & 0.005 \\
\hline Inert/Tannin & 1.500 \\
\hline \multirow[t]{2}{*}{ Total } & 100.00 \\
\hline & Calculated composition \\
\hline Metabolizable Energy(kcal/kg) & 3150 \\
\hline Crude Protein (\%) & 19.86 \\
\hline Digestible lysine (\%) & 1.131 \\
\hline Digestible methyonine + cystin $(\%)$ & 0.826 \\
\hline Digestible threonine $(\%)$ & 0.735 \\
\hline Calcium (\%) & 0.758 \\
\hline Available phosphorous (\%) & 0.354 \\
\hline Sodium $(\%)$ & 0.195 \\
\hline
\end{tabular}

${ }^{1}$ ROVIMIX - Vitamin suplement for poultry. Content: Vit A (min) 9000000 UI; Vit D3 (min) 2500000 UI; Vit E (min) 20000 UI; Vit K3 (min) 2500 mg; Vit B1 (min) 1500 mg; Vit B2 (min) 6000 mg; Vit B6 (min) 3000 mg; Pantotenic acid (min) 12 g; Niacin (min) $25 \mathrm{~g}$; Folic acid (min) $800 \mathrm{mg}$; Se (min) $250 \mathrm{mg}$; ${ }^{2}$ ROLIGOMIX - Mineral suplement for poultry. Content: $\mathrm{Cu}$ (min) $20 \mathrm{~g} ; \mathrm{Fe}$ (min) 100g; Mn (min) $2000 \mathrm{mg}$; Zn (min) $100 \mathrm{~g} ;{ }^{3} \mathrm{BHT} ;{ }^{4}$ Salinomycin 12\%; ${ }^{5}$ Virginamycin. 
The treatments consisted of diets with increasing levels of black wattle tannin (Acacia mearnsii) ( 0 , 250, 500, 750, 1000, and $1250 \mathrm{~g}^{-1}$ of tannin with $72 \%$ tannic acid). At 42 days of age, all birds and rations were weighed to determine the final weight (FW), weight gain (WG), feed intake (FI), and Feed conversion rate (FCR) and two birds per experimental unit were slaughtered to determine the carcass yield, cut yield (chest, thigh, drumstick and wing), and the relative weight of the abdominal fat and liver.

For morphological evaluation of the duodenum, $4 \mathrm{~cm}$ of the distal portion of the duodenum was collected. The portions of the duodenum were opened and histological sections and slides were prepared. The image capture of the slides was performed using an optical microscope. The measurements of villi and crypts were taken and from these values the mean height of the villus, depth of the crypt, and the vilo:crypt relationship were determined.

To statistically evaluate the effect of the use of acacia tannin on the variables an analysis of variance was performed, followed by the Dunnett test and polynomial regression analysis with the aid of the Statistical Analysis System, SAEG.

In the second experiment, 900 male 21-day-ofage broilers were used and distributed across 50 experimental units, consisting of 18 birds each, with a mean weight of $959.67 \pm 3.66$ grams, housed in a DIC two factorial scheme $(5,25,50,75,100 \%)$ of dietary fiber (Table 2), and one of the factors was supplementation (250 $\left.\mathrm{g} \mathrm{ton}^{-1}\right)$ or not with acacia tannin in the diet (Table 2). Calcitic limestone was substituted by golden mussel meal in the feed, totaling 10 treatments with five replicates each.

Table 2. Experimental diets composition.

\begin{tabular}{|c|c|c|c|c|c|}
\hline \multirow[b]{2}{*}{ Ingredients $(\%)$} & \multicolumn{5}{|c|}{ Replacement level (\%) of the limestone by golden mussel } \\
\hline & 0 & 25 & 50 & 75 & 100 \\
\hline Corn grain & 59.26 & 59.16 & 59.05 & 58.95 & 58.85 \\
\hline Soybean meal & 32.02 & 32.04 & 32.06 & 32.07 & 32.08 \\
\hline Degummed soy oil & 4.900 & 4.935 & 4.971 & 5.008 & 5.043 \\
\hline Dicalcium phosphate & 1.341 & 1.341 & 1.341 & 1.341 & 1.341 \\
\hline Limestone & 0.888 & 0.666 & 0.444 & 0.222 & 0.000 \\
\hline Golden mussel & 0.000 & 0.274 & 0.548 & 0.822 & 1.096 \\
\hline Salt & 0.400 & 0.400 & 0.400 & 0.400 & 0.400 \\
\hline DL-methionine $99 \%$ & 0.281 & 0.285 & 0.285 & 0.286 & 0.286 \\
\hline L-lysine $78 \%$ & 0.241 & 0.244 & 0.244 & 0.244 & 0.243 \\
\hline L-threonine99\% & 0.103 & 0.109 & 0.109 & 0.109 & 0.110 \\
\hline Vitamin suplement $^{1}$ & 0.100 & 0.100 & 0.100 & 0.100 & 0.100 \\
\hline Mineral suplement ${ }^{2}$ & 0.050 & 0.050 & 0.050 & 0.050 & 0.050 \\
\hline Choline chloride $60 \%$ & 0.060 & 0.060 & 0.060 & 0.060 & 0.060 \\
\hline Antioxidant $^{3}$ & 0.060 & 0.060 & 0.060 & 0.060 & 0.060 \\
\hline Coxistac $^{4}$ & 0.020 & 0.020 & 0.020 & 0.020 & 0.020 \\
\hline Stafac $500^{5}$ & 0.000 & 0.005 & 0.005 & 0.005 & 0.005 \\
\hline Inert (washed sand) & 0.250 & 0.250 & 0.250 & 0.250 & 0.250 \\
\hline Total & 100.00 & 100.00 & 100.00 & 100.00 & 100.00 \\
\hline
\end{tabular}


continuation

\begin{tabular}{lccccc}
\hline \multicolumn{5}{c}{ Calculated composition } \\
\hline Metabolizable Energy(kcal/kg) & 3150 & 3150 & 3150 & 3150 & 3150 \\
Crude Protein (\%) & 19.46 & 19.46 & 19.46 & 19.46 & 19.46 \\
Digestible lysine (\%) & 1.131 & 1.131 & 1.131 & 0.131 & 0.131 \\
Digestible methyonine + cystin (\%) & 0.826 & 0.826 & 0.826 & 0.826 & 0.826 \\
Digestible threonine (\%) & 0.735 & 0.735 & 0.735 & 0.735 & 0.735 \\
Digestible valine (\%) & 0.795 & 0.795 & 0.795 & 0.795 & 0.795 \\
Calcium (\%) & 0.758 & 0.758 & 0.758 & 0.758 & 0.758 \\
Available phosphorous (\%) & 0.354 & 0.354 & 0.354 & 0.354 & 0.354 \\
Sodium (\%) & 0.177 & 0.177 & 0.177 & 0.177 & 0.177 \\
\hline
\end{tabular}

${ }^{1}$ ROVIMIX - Vitamin suplement for poultry. Content: Vit A (min) 9000000 UI; Vit D3 (min) 2500000 UI; Vit E (min) 20000 UI; Vit K3 (min) 2500 mg; Vit B1 (min) 1500 mg; Vit B2 (min) 6000 mg; Vit B6 (min) 3000 mg; Pantotenic acid (min) 12 g; Niacin (min) $25 \mathrm{~g}$; Folic acid (min) $800 \mathrm{mg}$; Se (min) $250 \mathrm{mg}$; ${ }^{2}$ ROLIGOMIX - Mineral suplement for poultry. Content: Cu (min) $20 \mathrm{~g}$; Fe (min) 100g; Mn (min) $2000 \mathrm{mg}$; Zn (min) $100 \mathrm{~g} ;{ }^{3} \mathrm{BHT} ;{ }^{4}$ Salinomycin $12 \%$; ${ }^{5}$ Virginamycin.

Golden mussels were collected from the Itaipu Binacional reservoir, in Tanks-net, located in the biological refuge of the municipality of Santa Helena, PR. The mussel shells were ground (4 $\mathrm{mm}$ ) and samples of the obtained meal were sent for the analysis of dry matter, crude protein, and mineral matter. In the Laboratory of Environmental and Instrumental Chemistry, analyses were also performed for the quantification of the toxic metals, chromium $(\mathrm{Cr})$, cadmium $(\mathrm{Cd})$, and lead $(\mathrm{Pb})$, and also calcium $(\mathrm{Ca})$, using nitroperchloric digestion and the technique of Flame Atomic Absorption Spectrometry, flame mode (FAAS), to determine the levels. Phosphorus $(\mathrm{P})$ determination was performed using visible ultraviolet (UV-VIS) spectrophotometry.

The slaughter and tissue collection procedures and determination of the variables FI, FW, WG, FCR, carcass yield, breast, leg, wing, and relative fat, liver, and kidney weight were performed according to the methodology described for the previous experiment.

The thigh and chest were boned to obtain tibia and breast meat, respectively. The left tibia was weighed on a semi-analytical scale and the length was measured with a digital caliper and the Seedor
Index given by the ratio of the bone weight $(\mathrm{mg})$ to its length $(\mathrm{mm})$ was calculated to determine the bone density. To determine the bone strength, the Brookfield CT3 Texture Analyzer was used, and the values were expressed in kilograms of force (kgf).

Chemical analyses were performed on the liver, kidneys, breast meat, and tibia for the quantification of the toxic metals, $\mathrm{Cr}, \mathrm{Cd}$, and $\mathrm{Pb}$, and $\mathrm{Ca}$ and $\mathrm{P}$ in the tibia, which were performed according to the methodologies mentioned above.

Blood samples were also collected from the chickens at 42 days of age. The blood was centrifuged for serum separation, followed by serum $\mathrm{Ca}$ analysis using the Elitech Flexor EL 200 automatic biochemical analyzer.

A variance analysis was performed to verify the effects of the levels of substitution of calcitic limestone by golden mussel meal. A polynomial regression was used at the $5 \%$ significance level and an $\mathrm{F}$ test was used to evaluate the effect of acacia tannin, at the $5 \%$ level of significance.

\section{Results and Discussion}

The use of $250 \mathrm{~g}^{-1}$ ton $^{-1}$ of acacia tannin did not result in changes in the FI, FW, or WG of the birds 
compared to the control ration (Table 3). The above values similar to those of the control ration, inclusion of this amount negatively affected the FI and WG of the birds, however, for FCR, inclusion whereas inclusion above $1000 \mathrm{~g} \mathrm{ton}^{-1}$ worsened the of up to $750 \mathrm{~g}^{-1}$ of acacia tannin produced conversion of the chickens.

Table 3. Performance in broilers fed different levels of inclusion of tannin from 21 to 42 days of age.

\begin{tabular}{lcccc}
\hline Tannin $\left(\right.$ g ton $\left.^{-1}\right)$ & FI $(\mathrm{g})$ & FW $(\mathrm{g})$ & WG $(\mathrm{g})$ & FCR $(\mathrm{g} \mathrm{g})$ \\
\hline 0 & $3223.08 \mathrm{a}$ & $2822.69 \mathrm{a}$ & $1907.31 \mathrm{a}$ & $1.690 \mathrm{a}$ \\
250 & $3281.86 \mathrm{a}$ & $2860.00 \mathrm{a}$ & $1947.05 \mathrm{a}$ & $1.686 \mathrm{a}$ \\
500 & $3049.98 \mathrm{~b}$ & $2709.38 \mathrm{~b}$ & $1799.12 \mathrm{~b}$ & $1.696 \mathrm{a}$ \\
750 & $2998.07 \mathrm{~b}$ & $2679.65 \mathrm{~b}$ & $1769.52 \mathrm{~b}$ & $1.694 \mathrm{a}$ \\
1000 & $2827.89 \mathrm{~b}$ & $2529.23 \mathrm{~b}$ & $1621.28 \mathrm{~b}$ & $1.744 \mathrm{~b}$ \\
1250 & $2551.65 \mathrm{~b}$ & $2376.06 \mathrm{~b}$ & $1463.88 \mathrm{~b}$ & $1.743 \mathrm{~b}$ \\
\hline CV $(\%)$ & 2.31 & 1.76 & 1.39 \\
\hline \multicolumn{5}{c}{ Probability } \\
\hline Linear & 0.000 & 0.000 & 0.001 \\
Quadratic & 0.052 & 0.000 & 0.443 \\
\hline \multicolumn{5}{c}{ Regression equations } \\
CR & $3446.64-0.673006 \mathrm{x}$ & 0.90 \\
PF & $2975.27-0.459209 \mathrm{x}$ & 0.91 \\
GP & $2063.42-0.457671 \mathrm{x}$ & 0.91 \\
CA & \multicolumn{5}{c}{0.46} \\
\hline
\end{tabular}

$\mathrm{FI}=$ Feed intake; $\mathrm{FW}=$ Final weight; $\mathrm{WG}=$ Weight gain; $\mathrm{FCR}=$ Feed conversion rate; ${ }^{\mathrm{a}, \mathrm{b}}$ Values followed for the different letters and the same level of $5 \%$ significance; $\mathrm{CV}=$ Coefficient of variation (\%).

Evaluating the inclusion levels of acacia tannin revealed there was a linear decreasing effect $(\mathrm{P}<$ 0.05 ) for the FI, FW, and WG, however the FCR presented an increasing linear effect $(\mathrm{P}<0.05)$. These results indicate that an increase in acacia tannin reduces the growth of the birds, with the best performance achieved with the lowest level of tannin studied $\left(250 \mathrm{~g} \mathrm{ton}^{-1}\right)$. The decrease in poultry performance caused by increasing tannin levels might be explained by the fact that this compound is able to precipitate proteins and inhibit digestive enzymes (CHUNG et al., 1998).
The decrease in bird performance corroborates the results reported by Moyle et al. (2012) who used diets containing tannin from the lespedeza plant and observed a decrease in bird weight and an increase in FI with worsening FCR.

The carcass and overcoat yields presented a linear decreasing effect $(\mathrm{P}<0.05)$ of the inclusion of acacia tannin (Table 4). The lower performance of the birds observed in the field was reflected in the carcass yield, since the higher the weight of the birds at slaughter, the better the carcass yield. 
Tabela 4. Carcass, breast, thigh, drumstick, wing, and relative fat and liver weight in broilers fed different levels of inclusion of tannin from 21 to 42 days of age.

\begin{tabular}{|c|c|c|c|c|c|c|c|}
\hline Tannin $\left(\mathrm{g} \mathrm{ton}^{-1}\right)$ & Carcass $(\%)$ & Breast (\%) & Thigh (\%) & Drumstick (\%) & Wing $(\%)$ & Fat $(\%)$ & Liver $(\%)$ \\
\hline 0 & 71.60 & 38.19 & 13.86 & 15.00 & 10.22 & $2.35^{\mathrm{a}}$ & 2.52 \\
\hline 250 & 71.27 & 39.08 & 13.76 & 15.38 & 10.29 & $1.93^{\mathrm{a}}$ & 2.29 \\
\hline 500 & 71.47 & 38.40 & 13.85 & 15.20 & 10.32 & $1.63^{\mathrm{b}}$ & 2.50 \\
\hline 750 & 70.48 & 37.82 & 14.15 & 15.33 & 10.70 & $1.86^{\mathrm{a}}$ & 2.71 \\
\hline 1000 & 70.70 & 38.45 & 13.75 & 14.97 & 10.24 & $1.59^{\mathrm{b}}$ & 2.68 \\
\hline 1250 & 70.19 & 38.36 & 14.17 & 14.59 & 10.66 & $1.03^{\mathrm{b}}$ & 2.58 \\
\hline \multirow[t]{2}{*}{ CV (\%) } & 1.95 & 5.31 & 4.82 & 4.81 & 4.91 & 38.42 & 11.37 \\
\hline & \multicolumn{7}{|c|}{ Probability } \\
\hline Linear & 0.027 & 0.466 & 0.262 & 0.008 & 0.149 & 0.003 & 0.009 \\
\hline \multirow[t]{2}{*}{ Quadratic } & 0.885 & 0.291 & 0.939 & 0.249 & 0.885 & 0.150 & 0.012 \\
\hline & \multicolumn{5}{|c|}{ Regression equations } & \multicolumn{2}{|r|}{$\mathrm{R}^{2}$} \\
\hline Carcass & \multicolumn{5}{|c|}{$71.7059-0.00117773 x$} & \multicolumn{2}{|c|}{0,75} \\
\hline Drumstick & \multicolumn{5}{|c|}{$15.6379-0.00072790 \mathrm{x}$} & \multicolumn{2}{|c|}{0.78} \\
\hline Fat & \multicolumn{5}{|c|}{$2.15850-0.000735868 \mathrm{x}$} & \multicolumn{2}{|c|}{0.67} \\
\hline Liver & \multicolumn{5}{|c|}{$1.90311+0.001756 x-0.0000009709 x^{2}$} & \multicolumn{2}{|c|}{0.98} \\
\hline
\end{tabular}

a,bValues followed by different letters in the same column differ from the control treatment at the $5 \%$ level of significance; $\mathrm{CV}=$ Coefficient of variation (\%).

The carcass yield data corroborate the results of Garcia et al. (2005), who observed a decrease in the carcass weight of birds fed high tannin sorghum in compared to low tannin sorghum, however, there was no difference in the other cuts of the carcass. Carolino et al. (2014) also found that the use of sorghum grain with tannin did not influence the carcass yield.

The use of acacia tannin resulted in a lower abdominal fat deposition in birds slaughtered at 42 days of age, presenting a linear decreasing effect ( $\mathrm{P}$ $<0.05)$. This lower deposition is probably related to the agglutination of the tannin to the nutrients in the diet, which caused a worse performance and consequently leaner carcasses. Thus, Ramos et al. (2006), working with cashew pulp in the feeding of broilers, also obtained a tannin effect on fat deposition. The ability of condensed tannins to form complexes with enzymes might be the cause of the lower deposition of adipose tissue in the abdomens of the birds, since these impair the use of dietary lipids (CHUNG et al., 1998).

The use of acacia tannin provided a quadratic effect $(\mathrm{P}<0.05)$ on the relative weight of the liver at 42 days of age, with the highest weight of this organ observed with the inclusion of $896.75 \mathrm{~g} \mathrm{ton}^{-1}$ of tannin. Moyle et al. (2012) observed that when using $20 \%$ sericea lespedeza, a tannin rich grass, the relative liver weight increased compared to the control diet. The liver can be affected by the toxic effect of tannin, since it is responsible for coagulation factors, and also since it is the primary source of several serological metabolites including urea, albumin, and glucose (SILVA et al., 2011).

The inclusion levels of acacia tannin at 42 days of age did not have a significant effect $(\mathrm{P}>0.05)$ on the measures of villi height and crypt depth for the duodenal region, nor did the use of tannin influence the relationship vilo:crypt for this same segment (Table 5). 
Table 5. Morphometry of intestinal duodenum of broilers at 42 days fed diets containing different levels of inclusion of tannins from 21 to 42 days of age.

\begin{tabular}{lccc}
\hline Tannin $\left(\mathrm{g} \mathrm{ton}^{-1}\right)$ & Villus height $(\mu \mathrm{m})$ & Crypt depth $(\mu \mathrm{m})$ & Relation Villus height:Crypt depth \\
\hline 0 & 1322.74 & 120.32 & 11.58 \\
250 & 1438.78 & 115.88 & 12.54 \\
500 & 1523.68 & 119.29 & 13.26 \\
750 & 1351.85 & 128.05 & 11.09 \\
1000 & 1453.10 & 134.52 & 11.29 \\
1250 & 1343.42 & 121.37 & 11.41 \\
\hline CV $(\%)$ & 12.27 & 24.48 & 22.40 \\
\hline \multicolumn{4}{c}{ Probability } \\
\hline Linear & 0.238 & 0.404 & 0.195 \\
Quadratic & 0.654 & 0.446 & 0.762 \\
\hline
\end{tabular}

$\mathrm{CV}=\mathrm{Coefficient}$ of variation (\%).

The use of tannin in diets of broiler chickens generally compromises poultry performance as a result of the absorption capacity of the gastrointestinal tract being impaired by this substance. According to Mansoori et al. (2015), condensed tannins can decrease the absorption of nutrients through the intestinal wall, which is due to metabolic phenomena that inhibit the performance of enzymes present in the digestive system. Nyamambi et al. (2007), in a study with high tannin sorghum of different species and levels of utilization in relation to maize in the diets of broilers, also observed that the villus height and depth of the intestinal crypts of the duodenum were reduced with increasing levels of tannin in the diet, however this effect was not observed in the present study.
The chemical composition values of heavy metals in the golden mussel are presented in Table 6. The calcium content obtained from the mollusc is considered good when compared to other similar sources of calcium, as is the case with oyster meal, and it is attractive since, according to Rostagno et al. (2017), oyster meal contains $36.4 \%$ calcium.

The presence of $\mathrm{Cd}$ and $\mathrm{Cr}$ in the golden mussel meal used in the present study was not detected. The concentration of lead was $0.46 \mathrm{mg} \mathrm{kg}^{-1}$, remaining within the allowed maximum that is of $2.00 \mathrm{mg} \mathrm{kg}^{-1}$, however, the cumulative effect of the heavy metals can be a problem when consumed in large quantities or for extended periods.

Table 6. Chemical composition and levels of heavy metals of the golden mussel harvested from the surface of the water column.

\begin{tabular}{ccccc}
\hline Calcium $(\%)$ & Phosphorus (\%) & Cadmium $\left(\mathrm{mg} \mathrm{kg}^{-1}\right)$ & Chromium $\left(\mathrm{mg} \mathrm{kg}^{-1}\right)$ & Lead $\left(\mathrm{mg} \mathrm{kg}^{-1}\right)$ \\
\hline 30.55 & 0.38 & 0.00 & 0.00 & 0.46 \\
\hline
\end{tabular}

The low concentrations of heavy metals in the golden mussel can be explained as a function of the harvesting site, which was removed from tank nets and arranged on the surface of the water column, since, according to Marengoni et al. (2013), the concentration of metals in the sediments is higher than that found in the water column. 
There was interaction between the factors $(\mathrm{P}<0.05)$ only for feed consumption from 21 to 42 days of age only when the levels of 25 and 50 $\%$ of limestone replaced by mussel meal were fed for the broilers that received tannin-containing diets. In other levels of substitution, consumption was similar among birds fed or not fed tannin (Table 7). However, for tannin diets and for diets without supplementation, there was no significant adjustment of the models for the effect of the replacement level of calcitic limestone with golden mussel meal. When comparing tannin addition and non-tannin treatments at each mussel level, the treatment without the addition of tannin was superior for 25 and $75 \%$ of limestone replaced by golden mussel.

Table 7. Performance of broiler chickens submitted to diets with different levels of limestone replacement by golden mussel meal and addition or not of tannin in the diet from 21 to 42 days of age.

\begin{tabular}{|c|c|c|c|c|c|c|c|c|}
\hline \multirow{3}{*}{ Inclusion level } & \multicolumn{2}{|c|}{$\mathrm{FI}(\mathrm{g})$} & \multicolumn{2}{|c|}{$\mathrm{FW}(\mathrm{g})$} & \multicolumn{2}{|c|}{ WG $(\mathrm{g})$} & \multicolumn{2}{|c|}{ FCR (g g) } \\
\hline & \multicolumn{8}{|c|}{ Tannin } \\
\hline & No & Yes & No & Yes & No & Yes & No & Yes \\
\hline 0 & 2996.11 & 3009.80 & 2036.11 & 2050.92 & $3547.67^{\mathrm{a}}$ & $3581.51^{\mathrm{a}}$ & 1.743 & 1.746 \\
\hline 25 & 3052.88 & 3002.39 & 2089.54 & 2044.61 & $3613.08^{a}$ & $3492.46^{\mathrm{b}}$ & 1.729 & 1.708 \\
\hline 50 & 3033.89 & 3007.48 & 2072.78 & 2051.37 & $3570.22^{\mathrm{a}}$ & $3531.90^{\mathrm{a}}$ & 1.723 & 1.722 \\
\hline 75 & 3073.56 & 3004.44 & 2111.90 & 2045.00 & $3652.25^{\mathrm{a}}$ & $3473.44^{\mathrm{b}}$ & 1.729 & 1.699 \\
\hline 100 & 3022.22 & 3000.00 & 2060.56 & 2043.33 & $3567.22^{\mathrm{a}}$ & $3537.56^{\mathrm{a}}$ & 1.731 & 1.732 \\
\hline Mean & $3055.73^{\mathrm{a}}$ & $3004.82^{b}$ & $2074.18^{\mathrm{a}}$ & $2047.05^{\mathrm{b}}$ & 3590.09 & 3523.37 & 1.731 & 1.721 \\
\hline Tannin & \multicolumn{2}{|c|}{0.014} & \multicolumn{2}{|c|}{0.031} & \multicolumn{2}{|c|}{0.001} & \multicolumn{2}{|c|}{0.183} \\
\hline Golden mussel & \multicolumn{2}{|c|}{0.377} & \multicolumn{2}{|c|}{0.419} & \multicolumn{2}{|c|}{0.985} & \multicolumn{2}{|c|}{0.073} \\
\hline Interaction & \multicolumn{2}{|c|}{0.269} & \multicolumn{2}{|c|}{0.289} & \multicolumn{2}{|c|}{0.009} & \multicolumn{2}{|c|}{0.492} \\
\hline CV (\%) & \multicolumn{2}{|c|}{1.41} & \multicolumn{2}{|c|}{2.08} & \multicolumn{2}{|c|}{1.87} & \multicolumn{2}{|c|}{1.45} \\
\hline
\end{tabular}

FI $=$ Feed intake; FW = Final weight; $\mathrm{WG}=$ Weight gain; FCR = Feed conversion rate; ${ }^{\mathrm{a}, \mathrm{b}}$ Values followed for the different letters and the same level of $5 \%$ significance; $\mathrm{CV}=$ Coefficient of variation (\%).

The Ca present in the golden mussel presents the same properties of that present in the calcitic limestone, and this is due to the fact that the two ingredients are formed by the same material, calcium carbonate $\left(\mathrm{CaCO}_{3}\right)$ and according to Reece (2017), the Ca present in the $\mathrm{Ca}$ carbonate has high solubility, therefore, its particles are more readily available than the present in the cereals, thus increasing the absorption capacity.

Evaluation of the feed consumption in this study revealed that the $\mathrm{Ca}$ in golden mussel was adequate for the levels required by the animals, since a diet deficient in this mineral would cause an increase in the food intake, and an excess could cause a reduction, due to the low $\mathrm{Ca}$ palatability, which would reduce feed intake (VARGAS JUNIOR et al., 2003).

However, the use of acacia tannin at the level of $250 \mathrm{~g} \mathrm{ton}^{-1}$ was not influenced by the use of gilt mussel instead of calcitic limestone $(\mathrm{P}>0.05)$ influenced both variables negatively. The FCR results of 21 to 42 days of age were not influenced by the treatments used in this work.

The performance of the birds could be affected in the treatments with the addition of tannin due to the factors mentioned by Silva et al. (2009). a decrease in palatability of food and voluntary intake, a reduction in the digestibility of protein, carbohydrates, starch and lipids, and mainly an inhibition of some enzymes present in the digestive tract. 
A significant interaction was verified for the wing and leg yield $(\mathrm{P}<0.05)$ (Table 8$)$. Analysis of the interaction of these variables revealed there was a linear effect $(\mathrm{P}<0.05)$ on leg yield when the birds were fed diets without tannin, in which, as the percentage of limestone replacement by mussel was increased, the leg yield reduced. However, for the broilers that received diets supplemented with tannin, the effect of inclusion levels of mussel meal was quadratic $(\mathrm{P}<0.05)$, and a better leg yield with $35.80 \%$ replacement was estimated. As for the wing yield, it was not possible to adjust the polynomial equation as a function of the levels of mussel meal when the birds received a diet without addition of tannin. However, for the chickens that received this additive in the diets, the wing yield was influenced in a quadratic manner, estimating a better value with $17 \%$ replacement of the calcitic limestone. Using an $\mathrm{F}$ test to analyze the variables within each substitution level demonstrated that the yield of legs increased yield of non-addition of tannin to the levels of 0 and $100 \%$ of limestone per golden mussel and the yield the wings decreased with the replacement of $100 \%$ of limestone with mussel without the addition of tannin.

Table 8. Carcass, breast, leg and wing yield values of broilers submitted to diets with different levels of limestone replacement per golden mussel and addition or not of tannin in the diet from 21 to 42 days of age.

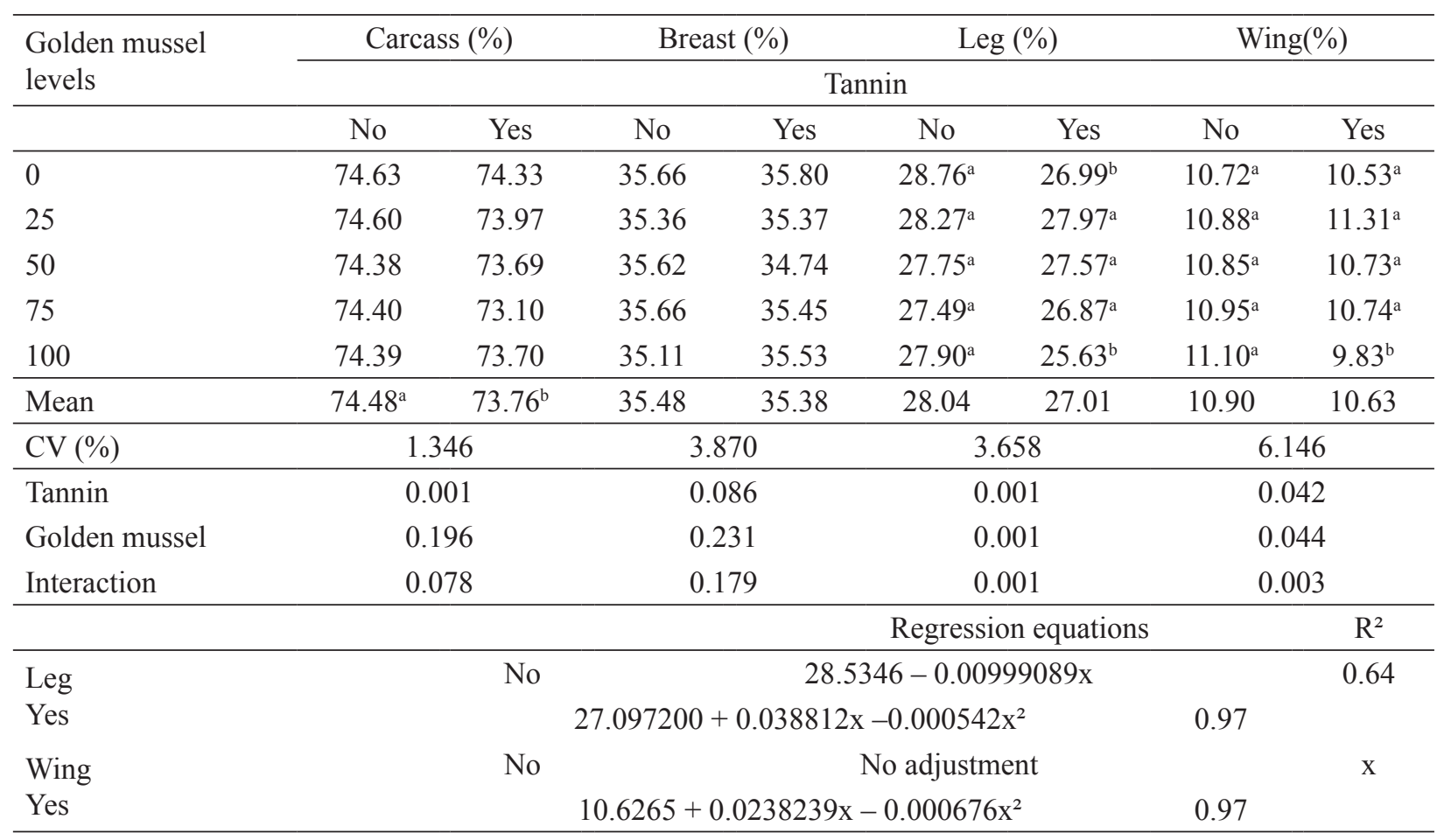

a,b Values followed by different letters in the same line differs on $\mathrm{F}$ test at the $5 \%$ level of significance; $\mathrm{CV}=\mathrm{Coefficient}$ of variation $(\%)$.

There was no interaction between the factors for carcass and chest yield and relative fat, liver, and kidney weight $(\mathrm{P}>0.05)$. Likewise, no effect of the limestone replacement level by mussel was observed on these variables $(\mathrm{P}>0.05)$. However, the addition of tannin had a negative effect on carcass yield and the relative weight of the kidneys $(\mathrm{P}<0.05)$, (Table 9) without influencing the breast yield and relative fat and liver weights $(\mathrm{P}>0.05)$. 
Table 9. Relative weights of fat, liver and kidney of broiler chickens submitted to diets with different levels of limestone replacement by golden mussel and addition or not of tannin in the diet from 21 to 42 days of age

\begin{tabular}{|c|c|c|c|c|c|c|}
\hline \multirow{3}{*}{$\begin{array}{l}\text { Golden mussel } \\
\text { levels }\end{array}$} & \multicolumn{2}{|c|}{ Relative fat weight (\%) } & \multicolumn{2}{|c|}{ Relative liver weight (\%) } & \multicolumn{2}{|c|}{$\begin{array}{c}\text { Relative weight of kidney } \\
(\%)\end{array}$} \\
\hline & \multicolumn{6}{|c|}{ Tannin } \\
\hline & No & Yes & No & Yes & No & Yes \\
\hline 0 & 1.72 & 1.58 & 2.37 & 2.42 & 0.53 & 0.46 \\
\hline 25 & 1.87 & 1.57 & 2.32 & 2.38 & 0.49 & 0.35 \\
\hline 50 & 1.63 & 1.82 & 2.40 & 2.42 & 0.47 & 0.43 \\
\hline 75 & 1.71 & 1.73 & 2.44 & 2.42 & 0.49 & 0.40 \\
\hline 100 & 2.19 & 1.74 & 2.39 & 2.38 & 0.53 & 0.41 \\
\hline Mean & 1.82 & 1.69 & 2.39 & 2.40 & $0.50^{\mathrm{a}}$ & $0.41^{\mathrm{b}}$ \\
\hline CV $(\%)$ & \multicolumn{2}{|c|}{23.646} & \multicolumn{2}{|c|}{7.951} & \multicolumn{2}{|c|}{23.893} \\
\hline Tannin & \multicolumn{2}{|c|}{0.115} & \multicolumn{2}{|c|}{0.143} & \multicolumn{2}{|c|}{0.001} \\
\hline Golden mussel & \multicolumn{2}{|c|}{0.143} & \multicolumn{2}{|c|}{0.295} & \multicolumn{2}{|c|}{0.250} \\
\hline Interaction & \multicolumn{2}{|c|}{0.118} & \multicolumn{2}{|c|}{0.198} & \multicolumn{2}{|c|}{0.145} \\
\hline
\end{tabular}

${ }^{a, b}$ Values followed by different letters in the same line differs on $\mathrm{F}$ test at the $5 \%$ level of significance; $\mathrm{CV}=\mathrm{Coefficient}$ of variation $(\%)$.

Similar results were reported by Garcia et al. (2005), who, working with birds fed low tannin sorghum, found a decrease in carcass weight, but no difference for the other cuts. However, Torres et al. (2013) reported that the use of low tannin sorghum did not have a significant effect on the carcass yield and cuts, as observed by Carolino et al. (2014), however they used high tannin sorghum in the evaluated diets.

Some effects, such as the inhibition of enzymes in the gastrointestinal tract, changes in cellular metabolism, and complexation with metallic ions might compromise some organs, such as the liver and kidneys, which act as filters in the body.

Analysis of the results of $\mathrm{P}, \mathrm{Ca}$, and ash in the bones at 42 days of age (Table 10) revealed that only ash showed an interaction between the factors studied $(\mathrm{P}<0.05)$. By performing data splitting and evaluating the effect of the level of substitution of calcitic limestone with golden mussel meal within the factors alone, it was possible to observe that, independently of the factors studied, there was no significant adjustment of the studied models.

There was no effect of the substitution levels on the other variables evaluated $(\mathrm{P}>0.05)$, however, the addition of tannin produced an increase in the $\mathrm{P}$ level in the bones $(\mathrm{P}<0.05)$ compared to the diets without tannin. These results demonstrate that the $\mathrm{Ca}$ and $\mathrm{P}$ availability of the sources used in the diets did not influence the deposition of $\mathrm{Ca}, \mathrm{P}$, and ash in the bone structure of the birds in the growth phase, that is, from 21 to 42 days of age.

For serum Ca levels, there was a significant effect of the replacement levels $(\mathrm{P}>0.05)$. Evaluating the effect of the level of substitution of calcitic limestone with golden mussel meal within the factors alone, demonstrated that a quadratic model was the best fit, with the lowest concentration of serum $\mathrm{Ca}$ at the $65.89 \%$ inclusion level of golden mussel. To maintain the serum Ca concentration as it decreases, the organism rapidly initiates the process of mobilization of bone $\mathrm{Ca}$ to raise plasma Ca levels to normal (VARGAS JUNIOR et al., 2003). 
Table 10. $\mathrm{P}, \mathrm{Ca}$ and ashes in natural matter in bones and calcium in broilers fed diets with different levels of limestone replacement by golden mussel and addition or not of tannin in the diet from 21 to 42 days of age.

\begin{tabular}{|c|c|c|c|c|c|c|c|c|}
\hline \multirow{3}{*}{$\begin{array}{c}\text { Golden mussel } \\
\text { levels }\end{array}$} & \multicolumn{2}{|c|}{ Phosphorus (\%) } & \multicolumn{2}{|c|}{ Calcium (\%) } & \multicolumn{2}{|c|}{ Ash (\%) } & \multicolumn{2}{|c|}{ Serum calcium $(\%)$} \\
\hline & \multicolumn{8}{|c|}{ Tannin } \\
\hline & No & Yes & No & Yes & No & Yes & No & Yes \\
\hline 0 & 2.26 & 2.30 & 16.12 & 16.22 & 42.66 & 40.96 & 8.66 & 9.69 \\
\hline 25 & 2.28 & 2.28 & 15.74 & 16.15 & 40.59 & 40.24 & 7.38 & 6.95 \\
\hline 50 & 2.30 & 2.36 & 17.62 & 16.98 & 38.81 & 41.30 & 7.20 & 8.18 \\
\hline 75 & 2.25 & 2.31 & 16.52 & 15.72 & 39.19 & 40.39 & 7.47 & 5.74 \\
\hline 100 & 2.25 & 2.31 & 15.13 & 15.98 & 40.93 & 39.70 & 8.27 & 6.78 \\
\hline Mean & $2.27^{\mathrm{b}}$ & $2.31^{\mathrm{a}}$ & 16.23 & 16.21 & 40.44 & 40.52 & 7.80 & 7.45 \\
\hline Tannin & \multicolumn{2}{|c|}{0.012} & \multicolumn{2}{|c|}{0.999} & \multicolumn{2}{|c|}{0.842} & \multicolumn{2}{|c|}{0.481} \\
\hline Golden mussel & \multicolumn{2}{|c|}{0.127} & \multicolumn{2}{|c|}{0.081} & \multicolumn{2}{|c|}{0.031} & \multicolumn{2}{|c|}{0.012} \\
\hline Interaction & \multicolumn{2}{|c|}{0.714} & \multicolumn{2}{|c|}{0.657} & \multicolumn{2}{|c|}{0.011} & \multicolumn{2}{|c|}{0.182} \\
\hline \multirow[t]{2}{*}{ CV (\%) } & \multicolumn{2}{|c|}{3.38} & \multicolumn{2}{|c|}{12.26} & \multicolumn{2}{|c|}{5.18} & \multicolumn{2}{|c|}{30.39} \\
\hline & \multicolumn{6}{|c|}{ Regression equation } & \multicolumn{2}{|c|}{$\mathrm{R}^{2}$} \\
\hline Serum calcium & \multicolumn{6}{|c|}{$9.01215+0.0640291 \mathrm{X}-0.000485870 \mathrm{X}^{2}$} & \multicolumn{2}{|c|}{0.76} \\
\hline
\end{tabular}

${ }^{a, b}$ Values followed by different letters in the same line differs on $\mathrm{F}$ test at the $5 \%$ level of significance; $\mathrm{CV}=\mathrm{Coefficient}$ of variation $(\%)$.

The results for the Seedor Index showed an of limestone replacement by the mussel meal for interaction $(\mathrm{P}<0.05)$ between the tannin and the diets without tannin was revealed, however, for golden mussel factors (Table 11). By dissecting this the diets with tannin addition, the adjustment was interaction, a linear decreasing effect of the levels linearly increasing.

Table 11. Seedor index and bone resistance (kgf) of broilers submitted to diets with different levels of limestone replacement by golden mussel and addition or not of tannin in the diet from 21 to 42 days of age.

\begin{tabular}{|c|c|c|c|c|}
\hline \multirow{3}{*}{$\begin{array}{l}\text { Golden mussel } \\
\text { levels }\end{array}$} & \multicolumn{2}{|c|}{ Seedor index } & \multicolumn{2}{|c|}{ Bone strength (kgf) } \\
\hline & \multicolumn{4}{|c|}{ Tannin } \\
\hline & No & Yes & No & Yes \\
\hline 0 & 174.88 & 157.74 & 37.36 & 29.83 \\
\hline 25 & 170.74 & 166.72 & 36.74 & 32.72 \\
\hline 50 & 166.09 & 168.61 & 35.45 & 33.58 \\
\hline 75 & 159.29 & 168.13 & 37.29 & 31.00 \\
\hline 100 & 166.37 & 181.60 & 35.25 & 34.32 \\
\hline Mean & 167.47 & 168.56 & $36.42^{\mathrm{a}}$ & $32.29^{b}$ \\
\hline CV (\%) & \multicolumn{2}{|c|}{9.42} & \multicolumn{2}{|c|}{18.28} \\
\hline Tannin & \multicolumn{2}{|c|}{0.730} & \multicolumn{2}{|c|}{0.001} \\
\hline Golden mussel & \multicolumn{2}{|c|}{0.334} & \multicolumn{2}{|c|}{0.468} \\
\hline \multirow[t]{2}{*}{ Interaction } & \multicolumn{2}{|c|}{0.019} & \multicolumn{2}{|c|}{0.411} \\
\hline & \multicolumn{3}{|c|}{ Regression equations } & $\mathrm{R}^{2}$ \\
\hline \multirow{2}{*}{ Seedor index } & No & \multicolumn{2}{|c|}{$173.17-0.113925 X$} & 0.60 \\
\hline & Yes & \multicolumn{2}{|c|}{$158.736+0.196558 X$} & 0.83 \\
\hline
\end{tabular}

${ }^{a, b}$ Values followed by different letters in the same line differs on $\mathrm{F}$ test at the $5 \%$ level of significance; $\mathrm{CV}=\mathrm{Coefficient}$ of variation (\%). 
The results of bone resistance were not influenced by the level of mussel meal, and it was possible to replace $100 \%$ of the calcitic limestone in the rations without affecting the bony quality of the birds. The $\mathrm{Ca}$ is present mainly in the bones, which represents from 98 to $99 \%$ of all the Ca found in the organism (VARGAS JUNIOR et al., 2003).

In the analysis of toxic metals $(\mathrm{Cd}, \mathrm{Cr}$, and $\mathrm{Pb})$ in the breast meat, bones of the tibia, and organs (liver and kidneys), the presence of these metals was not detected and it was not possible to evaluate the adsorbent effect that the tannin should have on the metals at the levels tested in this study $(0,250$, $500,750,1000$, and $1250 \mathrm{~g} \mathrm{ton}^{-1}$ ). It should also be noted that the lack of metals makes it possible to safely use the birds for human consumption.

It should be noted that the golden mussel has low or no cost and its use in animal feed is an alternative destination for these invaders, reducing the use of mineral limestone, and resulting in a reduction in environmental impact.

\section{Conclusions}

The golden mussel harvested from the surface of the water column can be used in the form of flour as a source of calcium for broilers from 21 to 42 days of age, replacing up to $100 \%$ of the calcitic limestone. The use of acacia condensed tannin (Acacia mearnsii) at a level above $500 \mathrm{~g} \mathrm{ton}^{-1}$ of inclusion in the diet as a sequestrant of heavy metals in the golden mussel negatively affects the performance of the birds. The use of the golden mussel containing low concentrations of toxic metals does not cause contamination of the carcass and bird organs. It was not possible to observe the adsorbent effect of the acacia tannin on toxic metals at the concentrations used in this study.

\section{References}

BAYERLE,D.F.; NUNES, R.V.; GONÇALVESJUNIOR, A. C.; WACHHOLZ, L.; SCHERER, C.; SILVA, I. M.;
OLIVEIRA-BRUXEL, T. M.; VARGAS JUNIOR, J. G. Golden mussel (Limnoperna fortunei) in feed for broiler chicks using tannin as a sequestrant of toxic metals. Semina: Ciências Agrárias, Londrina, v. 38, n. 2, p. 843854, 2017. DOI: $10.5433 / 1679-0359.2017 \mathrm{v} 38 \mathrm{n} 2 \mathrm{p} 843$

CALEGARI, L.; LOPES, P. J. G.; OLIVEIRA, E.; GATTO, D. A.; STANGERLIN, D. M. Quantificação de taninos nas cascas de jurema-preta e acácia-negra. Pesquisa Florestal Brasileira, Colombo, v. 36, n. 85, p. 61-69, 2016. DOI: 10.4336/2016.pfb.36.85.986

CAROLINO, A. C. X. G.; SILVA, M. C. A.; LITZ, F. H.; FAGUNDES, N. S.; FERNANDES, E. A. Rendimento e composição de carcaça de frangos de corte alimentados com dietas contendo sorgo grão inteiro. Bioscience Journal, Uberlandia, v. 30, n. 4, p. 1139-1148, 2014.

CHUNG, K. T.; WONG, T. Y.; WEI, C. I.; HUANG, Y. W.; LIN, Y. Tannins and human health: a review. Critical Reviews in Food Science and Nutrition, Amherst, v. 38, n. 1, p. 421-464, 1998. DOI: 10.1080/10408699891274273

DARRIGRAN, G.; DAMBORENEA, C.; DRAGO, E. C.; EZCURRA de DRAGO, I.; PAIRA, A.; ARCHUBY, F. Invasion process of Limnoperna fortunei (Bivalvia: Mytilidae): the case of Uruguay River and emissaries of the Esteros del Iberá Wetland, Argentina. Zoologia, Curitiba, v. 29 , n. 6, p. 531-539, 2012. DOI: $10.1590 /$ S1984-46702012000600004

FIGUEIREDO, D. F.; MURAKAMI, E. A.; PEREIRA, S. A. M.; FURLAN, C. A.; TORAL, B. L. F. Desempenho e morfometria da mucosa de duodeno de frangos de corte alimentados com farelo de canola, durante o período inicial. Revista Brasileira de Zootecnia, Viçosa, MG, v. 32 , n. 6 , p. 1321-1329, 2003. DOI: 10.1590/S151635982003000600006

GARCIA, R. G.; MENDES, A. A.; ANDRADE, C.; PAZ, I. C. L. A.; TAKAHASHI, S. E.; PELÍCIA, K.; KOMIYAMA, C. M.; QUINTEIRO, R. R. Avaliação do desempenho e de parâmetros gastrintestinais de frangos de corte alimentados com dietas formuladas com sorgo alto tanino e baixo tanino. Ciência e Agrotecnologia, Lavras, v. 29 , n. 6 , p. $1248-1257$, 2005. DOI: $10.1590 /$ S1413-70542005000600020

LIMA, A. F. O.; SABIÁ, R. J.; TEIXEIRA, R. N. P.; SOBREIRA JÚNIOR, F. A. V. Gestão de resíduos eletroeletrônicos e seus impactos na poluição ambiental. Latin American Journal of Business Management, Taubaté, v. 6, n. 2, p. 109-126, 2015.

MANSOORI, B.; ROGIEWICZ, A.; SLOMINSKI, B. A. The effect of canola meal tannins on the intestinal absorption capacity of broilers using a $\mathrm{D} \square$ xylose test. Journal of Animal Physiology and Animal Nutrition, 
New York, v. 99, n. 6, p. 1084-1093, 2015. DOI: 10.1111/ jpn. 12320 .

MARENGONI, N. G.; KLOSOWSKI, E. S.; OLIVEIRA, K. P.; CHAMBO, A. P. S.; GONÇALVES JUNIOR, A. C. Bioacumulação de metais tóxicos e nutrientes no mexilhão dourado do reservatório da usina hidrelétrica de itaipu binacional. Química Nova, São Paulo, v. 36, n. 3, p. 359-363, 2013. DOI: 10.1590/S010040422013000300002

MARTINEZ, F. L. Taninos vegetais e suas aplicações. Rio de Janeiro: Universidade do Estado do Rio de Janeiro, 1996. 83 p.

MOYLE, J. R.; BURKE, J. M.; FANATICO, A.; MOSJIDIS, J. A.; SPENCER, T.; ARSI, K.; REYESHERRERA, I.; WOO-MING, A.; DONOGHUE, D. J.; DONOGHUE, A. M. Palatability of tannin-rich sericea lespedeza fed to broilers. The Journal of Applied Poultry Research, Oxford, v. 21, n. 4, p. 891-896, 2012. DOI: 10.3382/japr.2012-00559

NAKANO, Y.; TAKESHITA, K.; TSUTSUMI, T. Adsorption mechanisms of hexavalent chromium by redox within condensed tannin gel. Water Research, London, v. 35, n. 2, p. 496-500, 2001. DOI: 10.1016/ S0043-1354(00)00279-7

NYAMAMBI, B.; NDLOVU, L. R.; NAYK, Y. S.; KOCK, N. D. Intestinal growth and function of broiler chicks fed sorghum based diets differing in condensed tannin levels. South African Journal of Animal Science, Pretoria, v. 37, n. 3, p. 202-214, 2007. DOI: 10.4314/ sajas.v37i3.4092

PANDEY, G.; MADHURI, S. Heavy metals causing toxicity in animals and fishes. Research Journal of Animal, Veterinary and Fishery Sciences, Indore, v. 2, n. 2, p. 17-23, 2014.

RAMOS, L. S. N.; LOPES, J. B.; FIGUEIRÊDO, A. V. de.; FREITAS, A. C.; FARIAS, L. A.; SANTOS, L. S.; SILVA, H. O. Polpa de caju em rações para frangos de corte na fase final: desempenho e características de carcaça. Revista Brasileira de Zootecnia, Viçosa, MG, v. 35 , n. 3 , p. $804-810$, 2006. DOI: 10.1590/S151635982006000300024

REECE, W. O. Dukes, fisiologia dos animais domésticos. 13. ed. Rio de Janeiro: Guanabara Koogan, 2017. 740 p.

ROSTAGNO, H. S.; ALBINO, L. F. T.; DONZELE, J. L.; GOMES, P. C.; OLIVEIRA, R. F.; LOPES, D. C.; FERREIRA, A. S.; BARRETO, S. L. T. Tabelas brasileiras para aves e suínos: composição de alimentos e exigências nutricionais. 4. ed. Viçosa, MG: UFV, 2017. $488 \mathrm{p}$.

SILVA, C. F.; LÔBO, K. M. S.; ATHAYDE, A. C. R.; SILVA, W.W.; LIMA, E. Q.; PEQUENO, N. F. Avaliação da resposta hematológica dos animais tratados com Typha domingensis Pers. e Operculina hamiltonii sobre nematoides gastrintestinais de caprinos. Revista Ciência e Agrotecnologia, Lavras, v.35, n.3, p.568-574, 2011. DOI: $10.1590 / \mathrm{S} 1413-70542011000300019$

SILVA, J. D. T.; DIAS, L. T. S.; MACHADO, C. R.; CARVALHO, M. R. B.; RIZZO, P. V. Uso de sorgo com baixo teor em taninos na alimentação de frangos de corte. Nucleus Animalium, Ituverava, v. 1, n. 2, p. 32-51, 2009. DOI: $10.3738 / 1982.2278 .281$

TORRES, K. A.; PIZAURO, J. M. J.; SOARES, C. P.; SILVA, T. G.; NOGUEIRA, W. C.; CAMPOS, D. M.; FURLAN, R. L.; MACARI, M. Effects of corn replacement by sorghum in broiler diets on performance and intestinal mucosa integrity. Poultry Science, Oxford, v. 92 , n. 6 , p. $1564-1571,2013$. DOI: $10.3382 /$ ps.201202422

VARGAS JUNIOR, J. G. D.; ALBINO, L. F. T.; ROSTAGNO, H. S.; GOMES, P. C.; CUPERTINO, E. S. Níveis nutricionais de cálcio e fósforo disponível para aves de reposição leves e semipesadas de 0 a 6 semanas de idade. Revista Brasileira de Zootecnia, Viçosa, v. 32, n. 6, p. 1919-1926, 2003. DOI: 10.1590/S151635982003000800016 